\title{
Racang Bangun Prototype Flyweel Untuk Meningkatkan Kinerja Generator
}

\author{
Lutfi Arba Diantoro $^{1}$, Winarso ${ }^{2}$,Arif johar Taufiq ${ }^{3}$ \\ Program Studi S1 Teknik Elektro, Universitas Muhammadiyah Purwokerto \\ Fakultas Teknik dan Sains, Universitas Muhammadiyah Purwokerto
}

\section{Informasi Makalah}

Dikirim, 17 Juli 2021

Direvisi, 30 November 2021

Diterima, 2 Desember 2021

\section{Kata Kunci:}

Flywheel, energi listrik, torsi, energi kinetik

\section{Keyword:}

Flywheel, Electrical energy, torque,energy kinetik

\begin{abstract}
INTISARI
Kebutuhan energi listrik setiap tahun semakin meningkat seiring dengan pertumbuhan ekonomi di negara kita, energi listrik saat ini masih banyak memanfaatkan energi fosil sebagai energi utama. Untuk mencari energi listrik alternaitf maka dapat memanfaatkan energi kinetik yang tersimpan pada flywheel. Penelitian ini bertujuan untuk mengetahui seberapa besar energi kinetik yang terkandung dalam Flywheel, dengan cara mengetahui berapa lama waktu yang dihasilkan oleh flywheel berputar sampai berhenti saat motor listrik di putuskan sumber energinya. Berdasarkan penelitian yang sudah dilaksanakan besarnya energi Flywheel dengan berat 4,9 kg diameter $20 \mathrm{~cm}$ menghasilkan energi listrik 2,86 joule (watt-detik), berat $7,1 \mathrm{~kg}$ diameter $20 \mathrm{~cm}$ menghasilkan energi listrik 3,98 joule(watt-detik) dan berat $25 \mathrm{~kg}$ diameter $30 \mathrm{~cm}$ menghasilkan energi listrik 16,33 joule(watt-detik). Jadi semakin berat dan besar diameter flywheel maka energi listrik yang dihasilkan semakin besar.
\end{abstract}

\begin{abstract}
The need for electrical energy is increasing every year in line with the economic growth in our country, electrical energy currently still uses fossil energy as the main energy. To find alternative electrical energy, it can utilize the kinetic energy stored in the flywheel. This study aims to determine how much kinetic energy is contained in the flywheel, by knowing how long the time produced by the flywheel rotates until it stops when the electric motor is disconnected from its energy source. Based on research that has been carried out the amount of energy Flywheel with a weight of $4.9 \mathrm{~kg}$ with a diameter of $20 \mathrm{~cm}$ produces electrical energy of 2.86 joules (watt-seconds), a weight of $7.1 \mathrm{~kg}$ with a diameter of $20 \mathrm{~cm}$ produces electrical energy of 3.98 joules (wattseconds). and a weight of $25 \mathrm{~kg}$ with a diameter of $30 \mathrm{~cm}$ produces 16.33 joules of electrical energy (watt-seconds). So the heavier and larger the diameter of the flywheel, the greater the electrical energy produced.
\end{abstract}

produced.

\section{Korespondensi Penulis:}

Lutfi Arba Diantoro

Program Studi Teknik Elektro

Fakultas Teknik dan Sains Universitas Muhammadiyah Purwokerto

JL. Raya Dukuhwaluh, Purwokerto, 53182

Email:lutfiarba17@gmail.com

\section{PENDAHULUAN}

Proses produksi pada sebuah pabrik manufactur adalah kegiatan yang selalu membutuhkan berrbagai macam jenis mesin listrik seperti motor induksi, motor dc, motor sinkron dan juga generator. Mesin-mesin litsrik tersebut merupakan pengkonversi energi dan selalu digunakan pada proses produksi, dimana pada mesin-mesin tersebut sumber energi digunakan dan dikonversikan menjadi kerja yang berguna,[1].Pada beberapa jenis mesin listrik, saat proses kerja berlangsung, fluktuasi daya listrik sering terjadi dan mempengaruhi kecepatan motor listrik menjadi tidak stabil serta akan menghambat proses produksi pada industri manufacture tersebut. [2] 
Ketidakstabilan kecepatan putar pada mesin listrik merupakan kejadian yang selalu timbul diakibatkan oleh perubahan beban pada motor atau perubahan daya aktif masuk ke generator. Ketidakstabilan kecepatan menunjukan adanya daya berlebih atau kurang pada mesin listrik dan menunjukan adanya daya kinetik yang ada pada sistem tersebut. Energi kinetik yang terdapat pada sistem produksi mesin listrik dapat disimpan keberadaanya. Flywheel, atau dalam bahasa Indonesia sering disebut sebagai roda gila, digunakan dengan tujuan sebagai penyimpanan energy kinetik, sistem ini akan menyimpan energy saat suplai melebihi kebutuhan dan melepaskannya saat suplai lebih kecil dari kebutuhan. [3]

Penyimpan energi flywheel memperoleh energi kinetik dalam bentuk inersia putar dan memanfaatkan torsi dari flywheel, dan menyimpannya dalam bentuk energi putaran cukup besar, kemudian melepaskannya ketika sistem energi kinetik tersebut membutuhkannya secara langsung dengan sangat cepat dan mudah [4].

Beberapa faktor yang bisa mempengaruhi kinerja penyimpan energi flywheel antara lain material, geometri, panjang dari flywheel. Flywheel atau sering juga disebut roda gila seperti yang kita ketahui adalah sebuah komponen yang merupakan sebuah lempengan logam cor yang berbentuk lingkaran yang karena beratnya dapat menahan perubahan kecepatan yang drastis sehingga gerak putaran poros mesin menjadi lebih halus dan lebih stabil [5]. Flywheel dengan konstruksi berbentuk lingaran padat memiliki kerapatan energi hingga ratusan kali lebih banyak dibandingkan dengan alat penyimpanan energi lainya seperti baterai atau capasitor dan kelebihan dari flywheel dapat menyimpan dan melepaskan energi dengan lebih cepat dari alat penyimpanan lainnya[6].

Penelitian yang dilakukan oleh Razali yaitu Uji fungsi pada rancang bangun mesin pembangkit listrik tanpa bahan bakar minyak yang meliputi uji mekanisme dan uji sistem flywheel serta generator dan menyimpulkan bahwa alat uji daya ini mudah digunakan dan dipelajari tetapi tetap memberikan hasil belum optimal.[7]. Berdasarkan beberapa penelitian diatas, maka pada penelitian ini akan dirancang sistem penyimpan energi kinetik dengan menggunakan beberapa dimensi dan masa flywheel yang berbeda untuk menggerakan generator dc berbeban.

\section{METODE PENELITIAN}

\subsection{Flowchart Sistem}

Penelitian sistem penyimpan energi kinetik flywheel dilaksanakan di Laboratorium Mesin Listrik, Teknik Elektro Universitas Muhammadiyah Purwokerto dimulai dengan studi literatur dilanjutkan dengan perancangan dimensi dan masa flywheel. Perakitan sistem dari mesin prime mover, generator dan flywheel di letakan dalam konstruksi besi dan dihubungkan dnegan roda pully. Pengujian dilakukan dengan memberikan energi putar dari prime mover kepada sistem. Langkah berikutnya adalah mencatat data pengujian berupa besaran listrik seperti tegangan, arus dan lama flywheel menyimpan energinya. Berikut diagram alir penelitian seperti pada gambar 1.

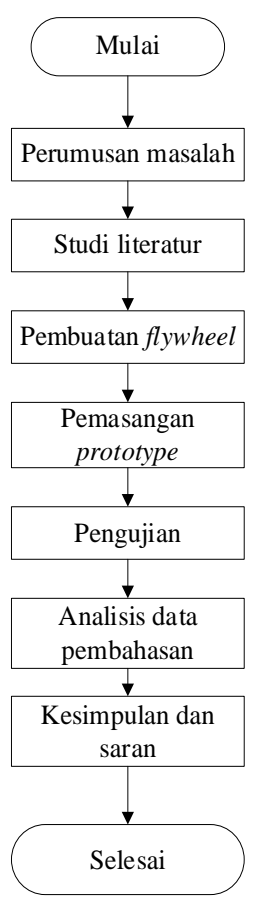

Gambar 1. Diagram Alir Penelitian 


\subsection{Prototype Sistem Penyimpan Energi Kinetik Flywheel}

Sistem penyimpan energi kinetik flywhell terdiri dari mesin penggerak berupa motor induksi tiga fasa, generator dc dan sistem Flywheel. Unit penyimpan energi kinetik ini di tempatkan pada kanal besi dengan terhubung dengan roda pully antar komponennya, sistem ini ditunjukan seperti gambar 2 berikut ini:

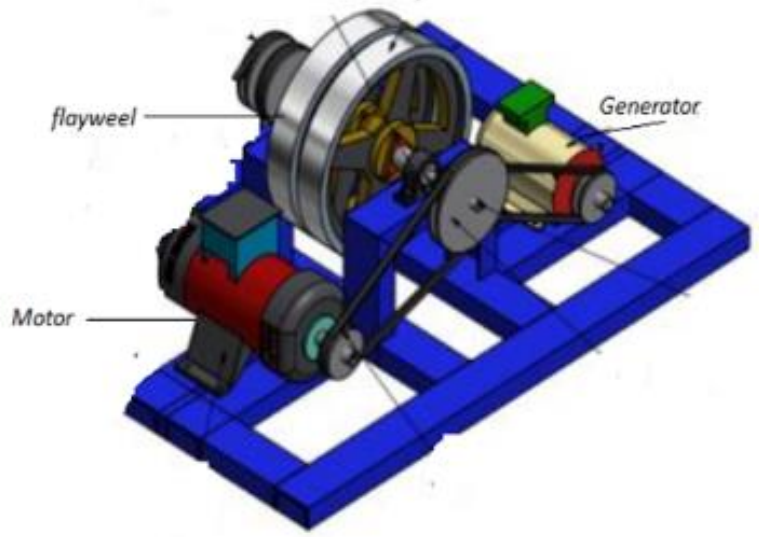

Gambar 2. Prototype Penguji Flywheel

Berikut adalah komponen-komponen pada prototipe sistem penguji flywheel:
a. Motor listrik 1 HP 3 fasa / 1420 RPM
b. Generator DC 12 volt
c. Dimensi krangka Prototype Flywheel $(10 \mathrm{~cm}, 15 \mathrm{~cm}$ dan $30 \mathrm{~cm})$
d. Diameter Pully flywheel $=3$ in
e. Diameter Pully motor $=5$ in
f. Diameter Pully generator $=4$ in
g. Panjang V-Belt Motor listrik - Poros Flywheel = $34 \mathrm{Cm}$ tipe B
h. Panjang V-Belt Generator - Poros Flywheel $=32 \mathrm{Cm}$ tipe B

\subsection{Alur Pengujian Flywheel}

Berikut ini adalah langkah-langkah dalam pengujian flywheel seperti pada gambar 3. berikut ini :

a. Sistem tegangan $220 \mathrm{Vac}$ di ubah oleh variabel speed drive (VSD) menjadi tegangan tiga fase 380 vac dan berfungsi sebagai pengatur kecepatan untuk motor tiga fasa.

b. VSD akan mengatur kecepatan yang di inginkan.

c. Motor penggerak akan memutar Flywheel dan mengkopel generator dc serta mensuplai beban listrik.

d. Flywheel akan memberikan tenaga yang tersimpannya saat energi yang diberikan ke motor dikurangi atau dihilangkan

e. Energi yang diberikan ke generator adalah energi dari motor listrik dan energi kinetik yang tersimpan di flywheel.

f. Energi kinetik yang tersimpan di flywheel tersebut digunakan untuk mensuplai lampu.

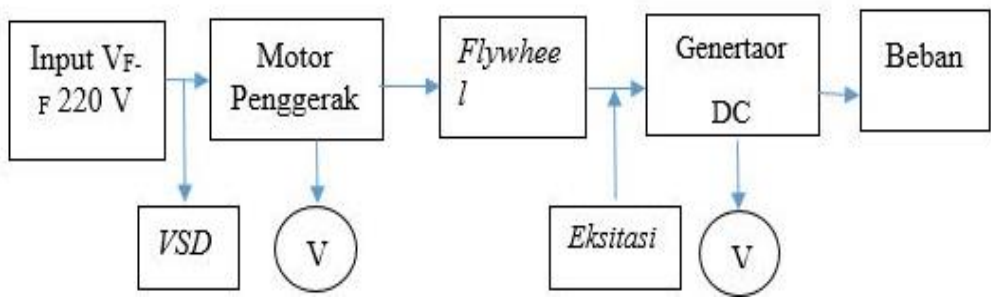

Gambar 3.Alur Pengujian Flywheel 


\section{HASIL DAN PEMBAHASAN}

\subsection{Pengujian Flywheel - generator tanpa beban}

Melakukan uji tegangan pada generator dc dengan menvariasikan arus eksitasi dan kecepatan, berikut adalah gambar pengujian generator tersebut..

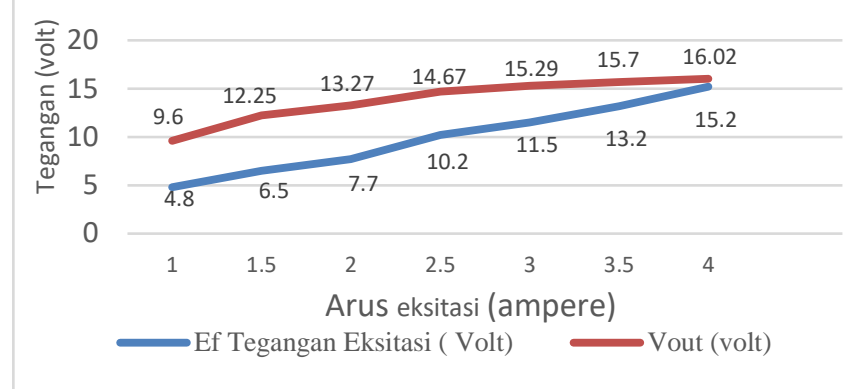

Gambar 4. Pengujian tegangan pada kecepatan 1035 rpm

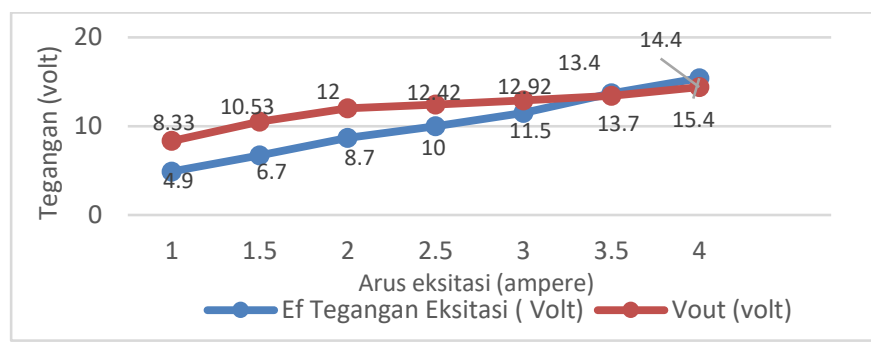

Gambar 5. Pengujian tegngan pada kecepatan $850 \mathrm{rpm}$

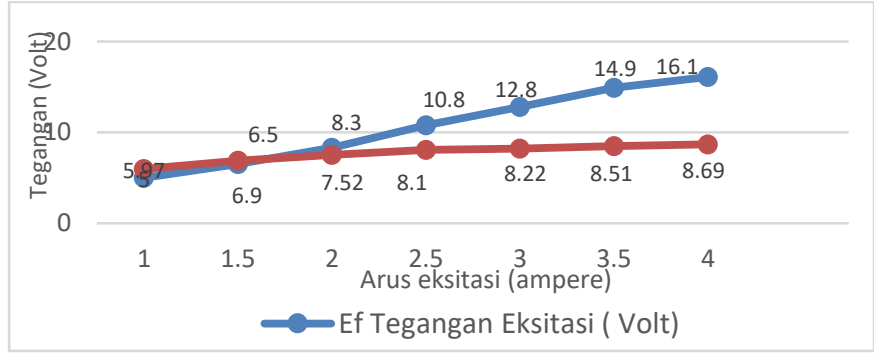

Gambar 6. Pengujian tegngan pada kecepatan 500 rpm

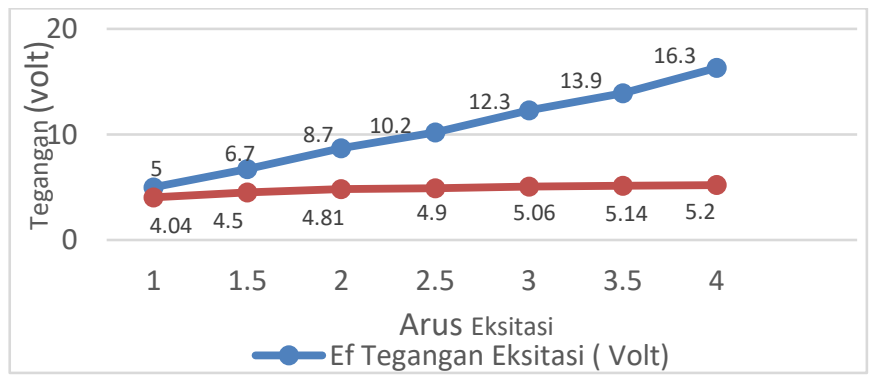

Gambar 7. Pengujian tegngan pada kecepatan 250 Rpm

Pengujian tegangan keluaran generator dilakukan dengan mengubah kecepatan (rpm) dan mengubah arus eksitasi If, dari gambar 4,5,6 dan 7 terlihat bahwa tegangan keluaran generator tanpa beban terhubung flywheel mengalami kenaikan saat tegangan eksitasi dan kecepatan di naikan dinaikan. Demikian juga tegangan keluaran juga turun saat eksitasi dan kecepatan juga diturunkan.

\subsection{Pengujian Flywheel Generator Berbeban}

Pengujian tegangan output generator dalam kondisi berbeban dengan mevariasikan arus eksitasi If 3.5 dan 4 amper pada kecepatan $1503 \mathrm{rpm}$, lihat gambar 8, 9 dan 10. berikut ini : 


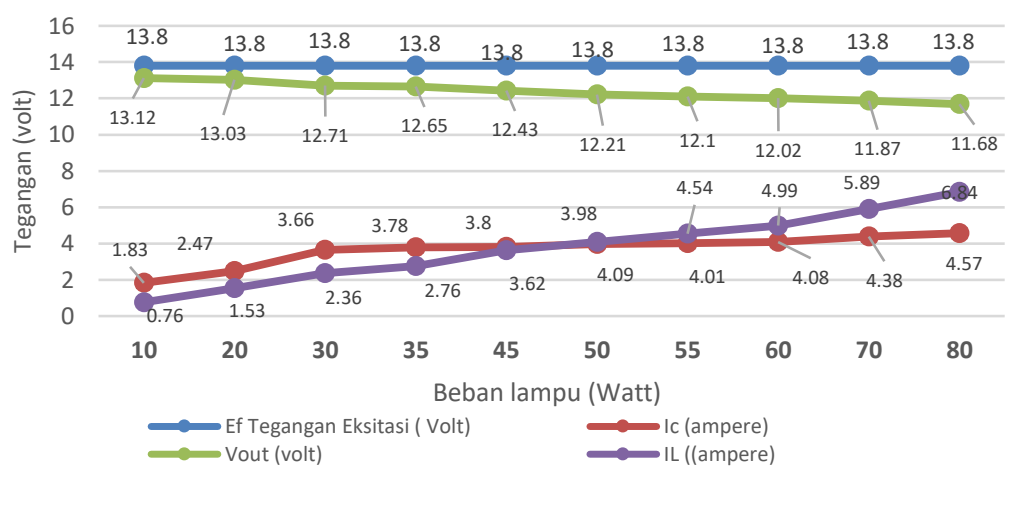

Gambar 8. Pengujian pembebanan generator, arus eksitasi 4 A, kecepatan 1035 Rpm

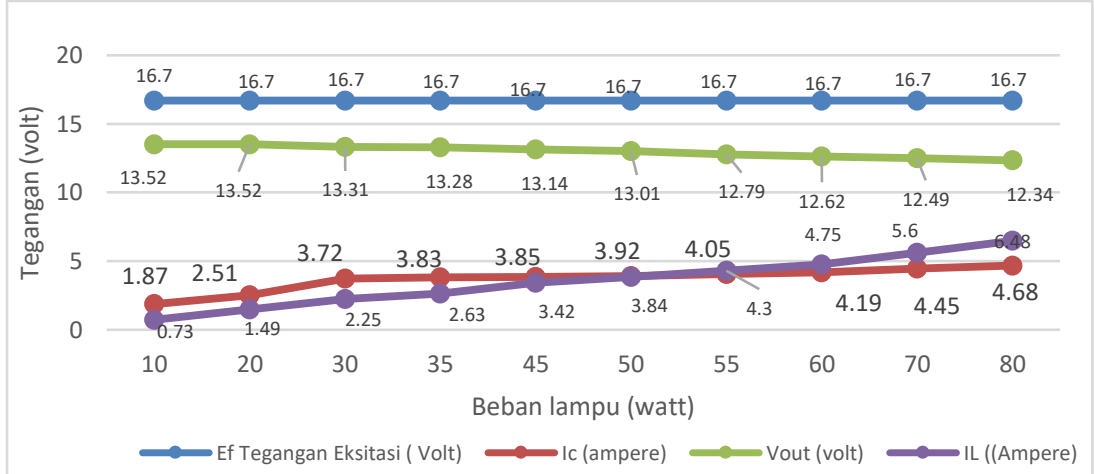

Gambar 9. Pengujian pembebanan generator ,arus eksitasi 3.5 A, kecepatan 1035 Rpm

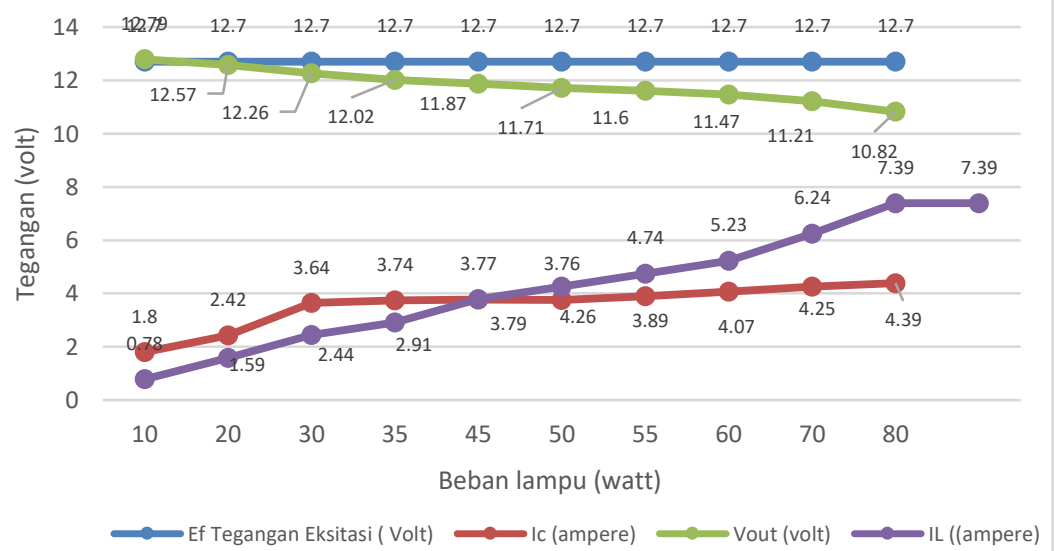

Gambar 10. Pengujian pembebanan generator ,arus eksitasi 3 A, kecepatan 1035 Rpm

Pengujian generator berbeban lampu pijar dengan kecepatan $1503 \mathrm{rpm}$, pada pembebanan maksimum 80 watt, arus ekistasi 3 , 3,5 dan 4 amper maka tegangan output generator adalah $10.82 \mathrm{~V} ; 12.34$ dan 11.68 volt dan arus bebannya adalah 7.39 A; 6.48 A dan 6.84 A. Dari hasil tersebut bahwa tegangan keluaran generator terpengaruh oleh besarnya beban lampu pijar dan terpengaruh oleh arus eksitasi.

\subsection{Pengujian Dimensi Dan Masa Flywheel Tanpa Beban}

Pengujian energi kinetik flywheel dilakukan dengan tanpa beban, yaitu mengukur waktu flywheel berputar sesaat motor di offkan sampai flywheel berhenti, lihat gambar 11. berikut ini : 


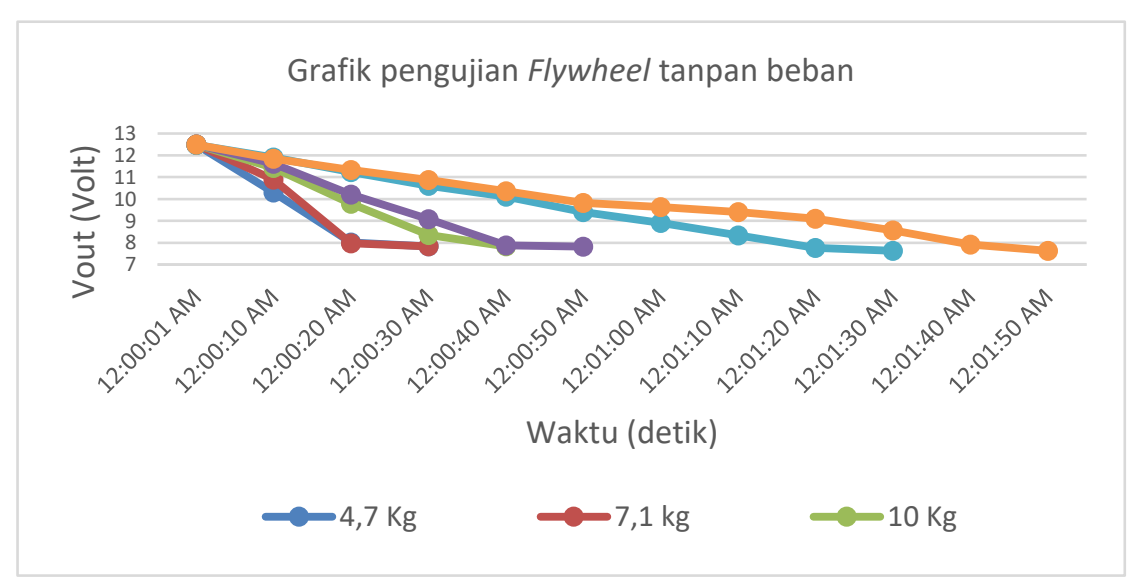

Gambar 12. Grafik pengujian flywheel tanpa beban

Pada pengujian flywheel berputar dengan lamanya waktu yang dihasilkan dari energi Flywheel itu sendiri, terlihat berat $4,7 \mathrm{Kg}$ memiliki waktu yang paling singkat dan flywheel dengan berat $25 \mathrm{Kg}$ memiliki waktu paling lama yaitu 1 menit 48 detik. Karena semakin berat dan besar diameter flywheel, maka torsi yang dimiliki flywheel akan semakin besar.

\subsection{Pengujian Flywheel Menggunkan Beban Lampu 5 Watt 12 Volt}

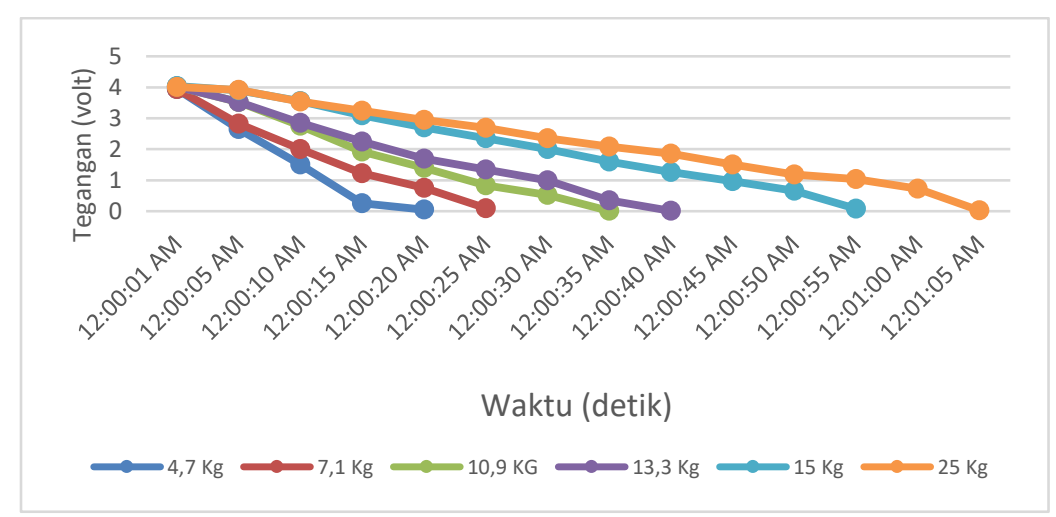

Gambar 13. Grafik pengujian flywheel tmenggunkan beban lampu 5 watt 12 volt

Pengujian flywheel terbebani lampu 5 watt dengan variasi masa dan dimensi menujukan bahwa energi yang tersimpan pada flywheel lebih banyak pada masa $25 \mathrm{~kg}$ dengan waktu 68 detik dan pada flywheel dengan berat $4,7 \mathrm{~kg}$ hanya dapat berputar dengan waktu 20 detik, ditunjukan pada gambar 13. Dari pengujian berbeban lampu 5 watt dapat menghitung energi yang dihasilkan dari flywheel sebgai berikut:

a. Perhitungan Enegri berat 4,7 Kg dan diameter flywheel $20 \mathrm{~cm}$ berbeban lampu 5 watt 12 volt .

$$
\begin{aligned}
& \text { Vrata }- \text { rata }=\frac{\text { Vtotal }}{t}= \\
& \text { Vrata }- \text { rata }=\frac{28,65}{18}=1.59 \text { Volt } \\
& \text { Irata }- \text { rata }=\frac{\text { Itotal }}{t}= \\
& \text { Irata }- \text { rata }=\frac{1,84}{18}=0,1 \text { Ampere }
\end{aligned}
$$

Menghitumg Energi yang di hasilkan

$$
\begin{aligned}
W & =V \times i \times t \\
& =1,59 \times 0,1 \times 18 \\
& =2,86 \text { watt }-\operatorname{det} i k
\end{aligned}
$$




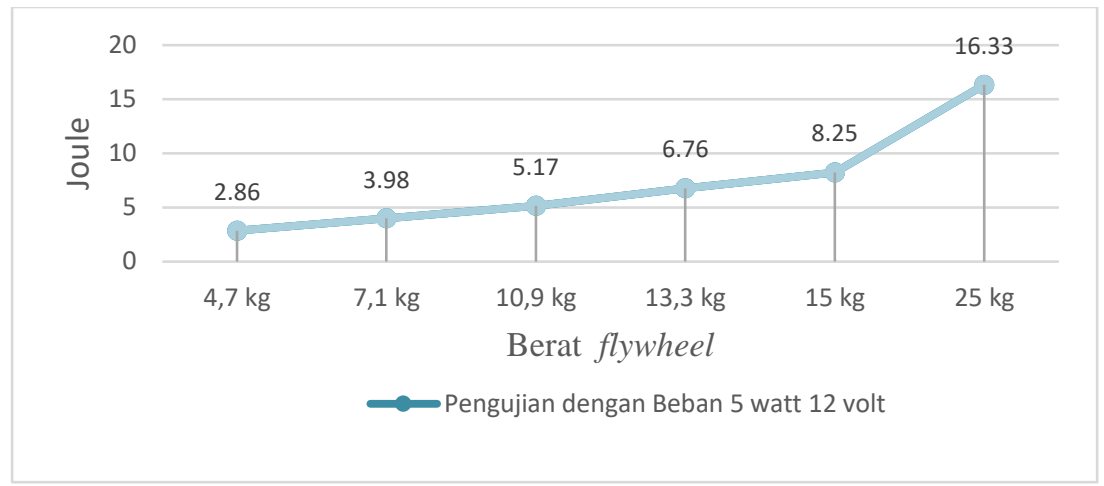

Gambar 14. Energi yang di hasilkan oleh beberapa flywheel

Dari gambar 14 dapat dijelaskan bahwa pengujian energi flywheel dilakukan dengan cara mematikan sumber motor listrik dan menghitung lamanya flywheel berputar sampai berhenti, dapat dilihat bahwa Flywheel dengan berat 4,7 kg memiliki energi 2.86 joule sedangkan flywheel dengan berat terbesar $25 \mathrm{~kg}$ memeiliki energi 16,33 joule menujukan, semakin berat dan besar diamter flywheel maka memiliki energi yang besar, karena semakin berat dan besar flywheel semakin besar pula torsinya.

\subsection{Perhitungan Moment Inersia Dan Torsi}

Untuk mengetahui energi yang tersimpan pada flywheel dengan variasi masa dan dimensi maka dapat dihitung dengan rumus moment inersia, kecepatan, percepatan, torsi dan daya yang di hasilkan flywheel, yaitu:

A. Masa flywheel 4,7 kg, dan diameter flywheel $20 \mathrm{~cm}$ :

Moment inersia :

$$
\text { I } \quad \begin{aligned}
= & \frac{1}{2} \times M \times R^{2} \\
& =\frac{1}{2} \times 4,7 \times 0,01 \\
& =0,0235 \mathrm{~kg} \mathrm{~m}^{2}
\end{aligned}
$$

Kecepatan sudut flywheel :

$$
\begin{aligned}
\Delta \omega & =\frac{n \times 2 \pi}{60} \\
& =\frac{1503 \times 2 \times 3,14}{60} \\
& =157,314 \mathrm{rad} / \mathrm{s}
\end{aligned}
$$

Percepatan sudut :

$$
\begin{aligned}
\alpha \quad & =\frac{\Delta \omega}{\Delta t} \\
& =\frac{157,314}{60} \\
& =2,621 \mathrm{rad} / \mathrm{s}^{2}
\end{aligned}
$$

Torsi flywheel :

$$
\begin{aligned}
\mathrm{T} & =I x \alpha \\
& =0,0235 \times 2,613 \\
& =0,0614 \mathrm{~N} \mathrm{~m}
\end{aligned}
$$

Daya yang dihasilkan flywheel :

$$
\begin{array}{ll}
\mathrm{P} & =\frac{T \times 2 \pi \times n}{60000} \\
\mathrm{P} & =\frac{0,0614 \times 2 \times 3,14 \times 1503}{60000} \\
& =0,0097 \mathrm{kw} \\
& =9,7 \mathrm{watt}
\end{array}
$$


B. Masa flywheel 7,1 kg dan diameter flywheel $20 \mathrm{~cm}$

Moment inersia :

$$
\text { I } \quad \begin{aligned}
= & \frac{1}{2} \times M \times R^{2} \\
& =\frac{1}{2} \times 7,1 \times 0,01 \\
& =0,0355 \mathrm{~kg} \mathrm{~m}^{2}
\end{aligned}
$$

Kecepatan sudut flywheel :

$\Delta \omega$

$$
\begin{aligned}
& =\frac{n \times 2 \pi}{60} \\
& =\frac{1503 \times 2 \times 3,14}{60} \\
& =157,314 \mathrm{rad} / \mathrm{s}
\end{aligned}
$$

Percepatan sudut :

$$
\begin{aligned}
\alpha & =\frac{\Delta \omega}{\Delta t} \\
& =\frac{157,314}{60} \\
& =2,621 \mathrm{rad} / \mathrm{s}^{2}
\end{aligned}
$$

Torsi flywheel :

$$
\begin{array}{rr}
T \quad I \times \alpha \\
=0,0355 \times 2,621 \\
=0,093 \mathrm{~N} \mathrm{~m}
\end{array}
$$

Daya yang dihasilkan flywheel :

$$
\begin{aligned}
\mathrm{P} & =\frac{T \times 2 \pi \times n}{60000} \\
& =\frac{0,093 \times 2 \times 3,14 \times 1503}{60000} \\
& =0,014 \mathrm{kw} \\
& =14 \mathrm{watt}
\end{aligned}
$$

Untuk mengetahui moment inersia, torsi dan daya yang dihasilkan oleh variasi flywheel, maka dapat dilihat pada tabel 1. berikut ini :

Tabel . 1 Hasil Perhitungan Moment Inersia Dan Torsi

\begin{tabular}{cccccc}
\hline Masa Flywheel & $\mathbf{4 , 7} \mathbf{~ k g}$ & $\mathbf{7 , 1} \mathbf{~ k g}$ & $\mathbf{1 3 , 9} \mathbf{~ k g}$ & $\mathbf{1 5} \mathbf{~ k g}$ & $\mathbf{2 5} \mathbf{~ k g}$ \\
$\begin{array}{c}\text { Moment inersia } \\
\text { Kecepatan }\end{array}$ & $0,0235 \mathrm{~kg} \mathrm{~m}^{2}$ & $0,0355 \mathrm{~kg} \mathrm{~m}^{2}$ & $0,0545 \mathrm{~kg} \mathrm{~m}^{2}$ & $0,15 \mathrm{~kg} \mathrm{~m}^{2}$ & $0,25 \mathrm{~kg} \mathrm{~m} \mathrm{~m}^{2}$ \\
& $157,314 \mathrm{rad} / \mathrm{s}$ & $157,314 \mathrm{rad} / \mathrm{s}$ & $157,314 \mathrm{rad} / \mathrm{s}$ & $157,314 \mathrm{rad} / \mathrm{s}$ & $157,314 \mathrm{rad} / \mathrm{s}$ \\
percepatan & $2,621 \mathrm{rad} / \mathrm{s}^{2}$ & $2,621 \mathrm{rad} / \mathrm{s}^{2}$ & $2,621 \mathrm{rad} / \mathrm{s}^{2}$ & $2,621 \mathrm{rad} / \mathrm{s}^{2}$ & $2,621 \mathrm{rad} / \mathrm{s}^{2}$ \\
& & & & & \\
Torsi & $0,0614 \mathrm{~N} \mathrm{~m}$ & $0,093 \mathrm{~N} \mathrm{~m}$ & $0,142 \mathrm{~N} \mathrm{~m}$ & $0,391 \mathrm{Nm}$ & $0,65 \mathrm{~N} \mathrm{~m}$ \\
$\begin{array}{c}\text { Daya yang } \\
\text { dihasilkan } \\
\text { flywheel }\end{array}$ & 9,7 watt & $14 \mathrm{watt}$ & $27 \mathrm{w}$ & $60 \mathrm{watt}$ & $100 \mathrm{watt}$ \\
\hline
\end{tabular}

Tabel 1.menujukan bawha berat dan besar diameter flyawheel memiliki pengaruh terhadap besarnya torsi dan daya yaitu pada berat flywheel $4,7 \mathrm{~kg}$ memiliki torsi $0,0614 \mathrm{Nm}$ sedangkan pada flywheel dengan berat $25 \mathrm{~kg}$ memiliki torsi $0,65 \mathrm{Nm}$, dari perbedaan torsi yang cukup besar berpengaruh terhadap daya yang di hasilkan oleh flywheel yaitu flywhell dengan berat 4,7 kg memiliki daya 9,7 watt, sedangkan $25 \mathrm{~kg}$ memiliki daya 100 watt. 


\section{KESIMPULAN}

Flywheel merupakan salah satu penyimpan energi yang dapat digunakan untuk menyimpan energi kinetik dan dapat diubah ke energi lain. Dari hasil penelitian yang telah dilakukan pengujian flywheel maka diperoleh kesimpulan bahwa flywheel dengan masa 4,7 kg dapat mnghasilkan torsi sebesar 0,0614 $\mathrm{Nm}$ dan daya listrik sebesar 9,7 watt. Besarnya energi ini berbanding lurus dengan dimensi dan masa yang dikandungnya yaitu pada flywheel dengan masa $15 \mathrm{~kg}$ dan $25 \mathrm{~kg}$ besarnya daya yang dihasilkan adalah 60 watt dan 100 watt. Dari hasil penelitian tersebut maka flywheel dapat diterapkan pada beberapa sistem konversi energi misalnya flywheel di terapkan pada sistem pembangkit listrik pikohidro, flywheel akan menyimpan kelebihan energi sementara yang dihasilkan oleh turnin air dan akan dikeluarkan saat putaran energi masuk turbin berkurang dan diharapkan akan menstabilkan putaran dan tegangan keluaran pembangkit pikohidro.

Untuk meningkatkan daya simpan pada flywheel maka untuk penelitian selanjutnya dalam merancang dimensi flywheel harus memperhitungkan jarak ukuran pully agar kecepatan dapat lebih tinggi sehingga energi yang tersimpan lebih lama, melakukan uji getaran dan memperhitngkan kekuatan rangka konstruksi flywheel.

\section{DAFTAR PUSTAKA}

[1] Djiteng Marsudi, Ir (2005).,’Pembangkitan Energi Listrik”, Ciracas Jakarta, Penerbit Erlangga.

[2] Razali, R., \& Stephan, S. (2017). Rancang Bangun Mesin Pembangkit Listrik Tanpa Bbm Berkapasitas 3000 Watt Dengan Memanfaatkan Putaran Flywheel. Jurnal Media Elektro, 45-48.

[3] British Electricity International (1991). Modern Power Station Practice: incorporating.

[4] Fakhrunnisa, R. (2015). Rancang Bangun Pembangkit Listrik Alternatif Dengan Menggunakan Roda Gila (Flywheel). Jurnal Elektro Politeknik Negeri Sriwijaya.

[5] Rachmawan, A. P., Ariana, I. M., \& Gerianto, I. (2014). Analisa Pengaruh Flywheel Daan FiringOrder Terhadap Proses Kerja Mesin Diesel. 1(1), 1-6.

[6] Sitepu, A., Sinaga, J., \& Sugiri, A. (2014). Kajian Eksperimental Pengaruh Bentuk Sudu Terhadap Unjuk Kerja Turbin Helik Untuk Sistem Pembangkit Listrik Tenaga Mikro Hidro (Pltmh). Jurnal Ilmiah Teknik Mesin FEMA, 2(2), 98597.

[7] Rokhim, M. A., \& Alfi, I. (2019). Rancang Bangun Generator Listrik Overunity Dengan Memanfaatkan Energi Yang Tersimpan Pada Flywheel (Roda Gila).Teknosains. http://eprints.uty.ac.id/3353/. 
